\title{
Monoclonal Antibodies Labeled with Polymeric Paramagnetic Ion Chelates
}

\author{
Paul Shreve AND Alex M. Aisen \\ Department of Radiology, University of Michigan Medical School, Ann Arbor, Michigan 48109
}

Received November 20, 1985

\begin{abstract}
Polymeric paramagnetic ion chelate molecules were synthesized and covalently linked to monoclonal antibodies. The labeled antibodies retained their antigen binding capacity in vitro while carrying up to an average of 50 paramagnetic ion chelates, enabling specifically bound antibody concentrations less than $2.0 \mu M$ to significantly reduce proton longitudinal relaxation times. (c) 1986 Academic Press, Inc.
\end{abstract}

The use of radiolabeled monoclonal antibodies (McAbs) as tissue-specific agents for external $\gamma$ camera imaging of tumors and other pathologies ( 1 ) has generated interest in the application of McAbs as tissue-specific carriers of paramagnetic contrast for MRI. Attempts to adapt this technology to MRI have been limited by the low concentration of $\mathrm{McAb}$ that can be specifically localized in a region of pathologic tissue relative to the level of chelated paramagnetic ion needed to significantly reduce local proton relaxation times. A reduction in the longitudinal relaxation time $\left(T_{1}\right)$ of $30 \%$ requires a free paramagnetic ion chelate concentration in the range of 50-100 $\mu M$ depending on the paramagnetic ion and chelate used (2). By conjugating the chelated paramagnetic ion directly to a macromolecule such that the ion's molecular correlation time is increased, marked enhancement of the paramagnetic ion-mediated reduction in $T_{1}$ has been reported, reducing the minimal paramagnetic ion concentration approximately sixfold (3). This enables McAbs bearing 3 to 4 chelates to reduce $T_{1}$ by $30 \%$ at $\mathrm{McAb}$ concentrations as low as $3 \mu \mathrm{M}$. Tumor associated cell surface antigens are generally found at a density of $10^{5}$ to $10^{6}$ sites per cell (1). The concentration of antigenic sites in tissue where cell concentration is $5 \times 10^{8}$ cells $/ \mathrm{ml}$ would thus be expected to fall in the range of $0.1-2.0 \mu M$. The tissue concentration of intravenously administered McAbs specifically localized in tumors in animal models used in immunoscintigraphy experiments, however, is far lower, typically only a few nanomolar $(4,5)$. Increasing the dose administered to the animals, using multivalent McAb cocktails or regional administration such as via lymphatics (6), may allow for greater tissue concentrations, possibly as high as $0.01-0.10 \mu \mathrm{M}$. Certain tissue antigens which exist at very high density might allow for tissue concentrations of specifically localized McAb to substantially exceed $1 \mu M(7)$. Still, such cases are rare and with most antigen targets submicromolar concentrations of specifically localized McAb are likely to be the upper limit in vivo. McAbs bearing only a few chelates per antibody, while useful as carriers of radioisotopes for immunoscintigraphic imaging, are thus very limited in use as tissue-specific carriers of paramagnetic ions for MRI contrast. 
While paramagnetic ion chelates directly conjugated to a macromolecule gain proton relaxation enhancement (3), the direct conjugation of more than 3 or 4 chelates per antibody markedly diminishes the antibody's immunoreactivity $(8)$. To increase the number of paramagnetic ions carried by a McAb even further requires the use of a separate polymeric chelate molecule covalently bound to the antibody. In this communication we describe methods of derivatizing McAb with polymeric chelate molecules. The modified antibodies retain their specific antigen binding capacity in vitro while carrying over 50 chelates of paramagnetic ions per antibody.

Polymeric chelate molecules were synthesized using deferoxamine chelates of $\mathrm{Fe}^{3+}$ or DTPA (diethylenetriaminepentaacetic acid) chelates of $\mathrm{Gd}^{3+}$. Deferoxamine possesses a free primary amine moiety which readily forms an amide bond with the acyl imidazole derivative of carboxylates. The free carboxylate groups of polyacrylic acid (average of 70 monomeric units) and polyglutamic acid (average of 90 units) were first converted to acyl imidazoles with carbonyldiimidazole in dry DMF and DMSO solvents, respectively, and then allowed to react with deferoxamine $\mathrm{Fe}^{3+}$ chelates in dry DMF. Subsequently, to provide free thiol functionality to the polymeric chelates, 2-mercaptoethylamine (molar stoichiometry 1.2:1 per polymer) was allowed to react with remaining acyl imidazoles and then the preparations dialyzed exhaustively against phosphate buffered saline to remove uncoupled chelate. It could then be determined spectrophotometrically that, of the available carboxylates on the polyacrylic and polyglutamic polymer backbones, $30 \%$ were coupled to deferoxamine.

Polymeric chelates using DTPA were synthesized by allowing the free primary amino groups of a polyamine such as polylysine to react with the cyclic anhydride of DTPA to form an amide linkage. DTPA dicyclic anhydride was allowed to react with polylysine (average 66 monomeric units) in an aqueous bicarbonate solvent. Following dialysis, chelation of $\mathrm{Fe}^{3+}$ allowed the spectrophotometric determination that $20 \%$ of the available free amines were coupled to DTPA. To provide free thiol functionality, a few remaining free amines were allowed to react with SPDP ( $N$-succinimidyl-3-(2-pyridyldithio) propionate).

TABLE 1

Polymeric Paramagnetic Ion Chelate Molecules

\begin{tabular}{lcccc}
\hline & $\begin{array}{c}\text { Average molecular } \\
\text { weight } \\
\text { (Da) }\end{array}$ & $\begin{array}{c}\text { Average number of } \\
\text { chelates carried } \\
\text { per polymer }\end{array}$ & $\begin{array}{c}\text { Relaxivity of } \\
\text { free paramagnetic } \\
\text { chelate } \\
\left(\mathrm{s}^{-1} \mathrm{~m} M^{-1}\right)\end{array}$ & $\begin{array}{c}\text { Relaxivity of } \\
\text { polymer-bound } \\
\text { paramagnetic } \\
\text { chelate }^{b} \\
\left(\mathrm{~s}^{-1} \mathrm{~m} M^{-1}\right)\end{array}$ \\
\hline $\begin{array}{c}\text { Polyacrylic } \\
\text { deferoxamine-Fe }\end{array}$ & 21,000 & 25 & 1.9 & 2.2 \\
$\begin{array}{c}\text { Polyglutamic } \\
\text { deferoxamine-Fe }\end{array}$ & 30,000 & 27 & 1.9 & 2.1 \\
$\begin{array}{l}\text { Polylysine } \\
\text { DTPA-Gd }\end{array}$ & 19,000 & 14 & 4.6 & 5.5 \\
\hline
\end{tabular}

${ }^{a}$ Based on gel exclusion chromatography $K_{\mathrm{av}}$.

${ }^{b} 20 \mathrm{MHz}$ at $25^{\circ} \mathrm{C}$. 
As expected, the polymeric chelate preparations all yielded a broad distribution of molecular weights. Sephacryl S-200 gel permeation chromatography was therefore used to isolate fractions which correspond to polymers containing 25-30 deferoxamine $\mathrm{Fe}^{3+}$ chelates or 14 DTPA Gd ${ }^{3+}$ chelates (Table 1 ). The polymeric chelate molecules were then coupled to purified $\mathrm{McAb}$ preparation by the heterobifunctional coupling agent SMCC (succinimidyl-4-( $N$-maleimidomethyl) cyclohexane-1-carboxylate) which forms an amide linkage with the antibody lysine $\xi$ amino residues and a thioether bond with the free thiol moiety of the polymeric chelate molecule. McAbs in phosphate buffered saline were first allowed to react with a molar excess of SMCC, the unreacted SMCC was removed by G75 Sephadex exclusion chromatography, and then the derivatized antibodies were added to a molar excess $(8: 1)$ of polymeric chelate. The unreacted polychelate could be readily removed by Sephacryl S-300 exclusion chromatography and the polymeric chelate coupled McAbs separated from free McAbs by DEAE ion exchange chromatography. The number of chelates bound per McAb was determined by spectophotometry and Lowry protein assay (deferoxamine- $\mathrm{Fe}^{3+}$ polychelates) or by chelation of radionuclide and Lowry protein assay (DTPA polychelate). SDS-polyacrylamide electrophoresis under reducing conditions of the preparations demonstrated reduced migration of primarily the heavy chain band corresponding to an increase of molecular weight in the range of 20,000 to 30,000 .

TABLE 2

Immunoreactivity and Relaxivity of Paramagnetic Ion Chelate-Labeled Monoclonal Antibodies (McAbs)

\begin{tabular}{|c|c|c|c|c|}
\hline & $\begin{array}{c}\text { Chelates } \\
\text { per } \\
\text { McAb }\end{array}$ & $\begin{array}{l}\text { Immuno- } \\
\text { reactivity } \\
\text { of labeled } \\
\text { McAb } \\
(\%)\end{array}$ & $\begin{array}{c}\text { Relaxivity per } \\
\text { paramagnetic ion } \\
\text { chelate } \\
\left(\mathrm{s}^{-1} \mathrm{~m} M^{-1}\right)\end{array}$ & $\begin{array}{l}\text { Relaxivity } \\
\text { per McAb } \\
\left(\mathrm{s}^{-1} \mathrm{~m} M^{-1}\right)\end{array}$ \\
\hline \multicolumn{5}{|c|}{$\begin{array}{l}\text { Polyacrylic deferoxamine- } \mathrm{Fe}^{3+} \\
\text { coupled to } \mathrm{McAb}\end{array}$} \\
\hline 5:1 SMCC:McAb ${ }^{a}$ & 30 & 43 & 2.2 & 66 \\
\hline 15:1 SMCC:McAb & 52 & 31 & 2.2 & 114 \\
\hline \multicolumn{5}{|c|}{$\begin{array}{l}\text { Polyglutamic deferoxamine-Fe } \\
\text { coupled to } \mathrm{McAb}\end{array}$} \\
\hline 5:1 SMCC:McAb & 34 & 42 & 2.1 & 71 \\
\hline 15:1 SMCC:McAb & 58 & 32 & 2.1 & 122 \\
\hline \multicolumn{5}{|l|}{$\begin{array}{l}\text { Polylysine DTPA- } \mathrm{Gd}^{3+} \\
\text { coupled to } \mathrm{McAb}\end{array}$} \\
\hline 5:1 SMCC:McAb & 16 & 41 & 5.6 & 89 \\
\hline 15:1 SMCC:McAb & 30 & 30 & 5.6 & 168 \\
\hline \multicolumn{5}{|l|}{$\begin{array}{l}\text { DTPA-Gd }{ }^{3+} \text { directly } \\
\text { coupled to McAb }\end{array}$} \\
\hline 20:1 cDTPA:McAB ${ }^{b}$ & 0.8 & 56 & 21 & 17 \\
\hline 100:1 cDTPA:McAb & 3.2 & 36 & 21 & 67 \\
\hline 250:1 cDTPA:McAb & 6.3 & 17 & 21 & 132 \\
\hline
\end{tabular}

${ }^{a} \mathrm{McAb}$ at $3 \mathrm{mg} / \mathrm{ml}$ in phosphate buffer, $\mathrm{pH} 7.2$, allowed to react with $\mathrm{SMCC}$ for $30 \mathrm{~min}$ at $23^{\circ} \mathrm{C}$.

${ }^{b} \mathrm{McAb}$ at $1 \mathrm{mg} / \mathrm{ml}$ in $0.1 \mathrm{M}$ bicarbonate buffer, $\mathrm{pH} 8.2$, allowed to react with dicyclic anhydride DTPA for $1 \mathrm{~h}$ at $23^{\circ} \mathrm{C}$. 
To determine the fraction of immunoreactive conjugated antibody, McAb polymeric chelate conjugates were labeled with ${ }^{55} \mathrm{Fe}$ and incubated with appropriate target cells under conditions of antigen excess. Parallel experiments were performed using McAbs labeled directly with DTPA by the dicyclic anhydride method (8). Immunoreactive fractions of the polymeric chelate conjugated McAbs comparable to that obtained with DTPA-labeled McAbs (2-3 chelates per McAb) are observed when SMCC:McAb stoichiometry is low (5:1) and consequently the number of chelates carried per McAb fairly low. Higher SMCC loading and consequently more than one polychelate per $\mathrm{McAb}$ yielded expected increases in chelates carried per McAb at the expense of immunoreactivity (Table 2 ).

The relaxivity of the paramagnetic ion chelates is not changed significantly when the chelates are coupled to the polymeric supports or when the polymeric supports are in turn conjugated to the McAbs (Tables 1 and 2), suggesting the chelates enjoy a significant degree of rotational freedom when linked to the polymer backbones. When the polymeric paramagnetic ion chelate conjugated McAbs are allowed to specifically saturate the target surface antigens of cells in suspension $\left(5 \times 10^{6} \mathrm{cells} / \mathrm{ml}\right)$, the cells washed three times and then brought to packing density $\left(7.5 \times 10^{5}\right.$ cells $\left./ \mu \mathrm{l}\right)$, the decrease in $T_{1}$ of the packed cells is consistent with the antibody concentration (measured using radiolabeled McAbs) and the average number of chelates carried per McAb (Table 3).

Thus, by use of polymeric paramagnetic ion chelates, it becomes possible to significantly reduce $T_{1}$ with McAb specifically bound to cell surface antigens in vitro. In these experiments the lower limit of McAb concentration required to significantly

\section{TABLE 3}

Effect of Antigen-Specific Bound Paramagnetically Labeled Monoclonal Antibody on the Longitudinal Relaxation Time of Packed Daudi Cells

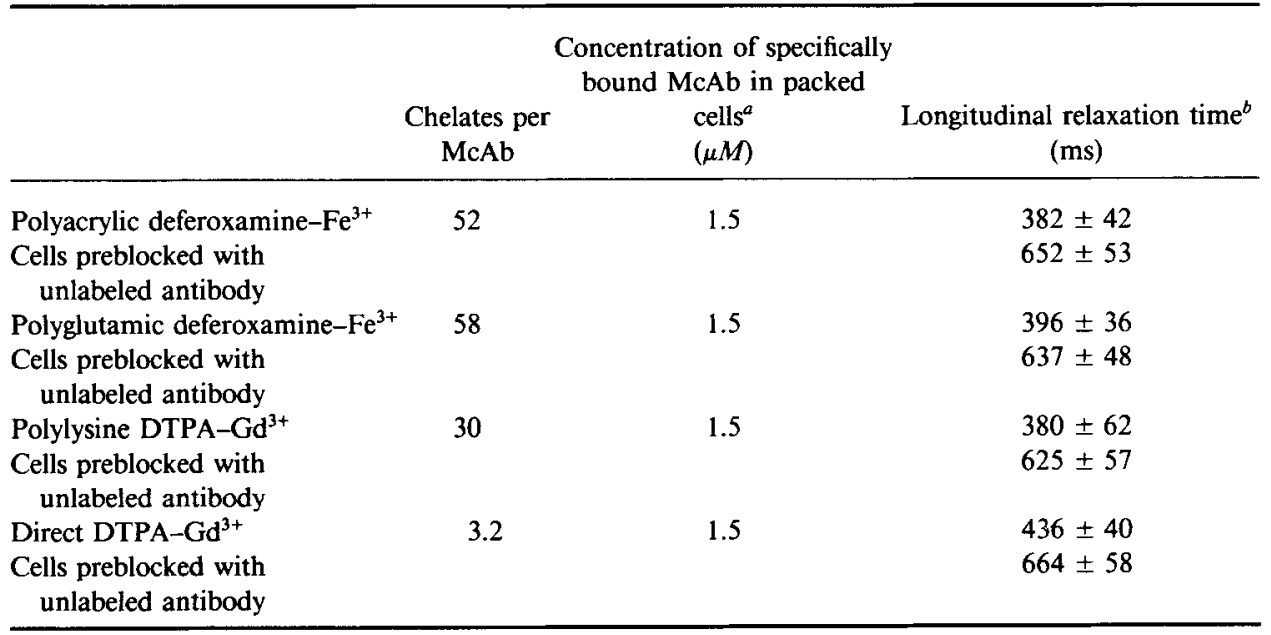

\footnotetext{
${ }^{a}$ Determined in a parallel assay using radiolabeled antibody.

${ }^{b} 20 \mathrm{MHz}$ at $25^{\circ} \mathrm{C}, 7.5 \times 10^{5}$ cells $/ \mu \mathrm{l}, 30 \mu \mathrm{l}$ total volume. Values are means of triplicate experiments \pm standard deviation.
} 
reduce $T_{1}(\sim 30 \%$ reduction) appears to be roughly $1.5 \mu M$. Further refinements such as polychelate molecules which are larger or have higher levels of chelate substitution and site-specific coupling of the polymeric chelate to the McAb could be used to improve the immunoreactivity of preparations that can significantly reduce $T_{1}$ at submicromolar concentrations. If polymeric chelate molecules can be designed to increase the chelated ion's effective correlation time such that proton relaxation enhancement occurs (3), the required McAb concentration might be reduced to $0.2 \mu M$ or less. It may be possible to achieve such specifically bound antibody concentration in vivo in tissues containing high levels of available target antigens, but with tumor associated antigens even $0.2 \mu M$ would be extremely difficult to reach in most circumstances. It should also be noted that typically only a few percent of the intravenously administered McAb localizes in the target tissue $(4,5)$ so that to reach a concentration of $0.2 \mu M$ in the target tissue comprising $0.5 \%$ body weight would require nearly 1 $\mathrm{mg}$ of labeled antibody for a mouse, or over $1000 \mathrm{mg}$ for a human subject; a substantial dose of a potentially immunogenic biologic.

These numerical realities should be kept in mind with regard to assessing potential usefulness of McAbs as tissue-specific carriers of paramagnetic contrast for MRI. The low density of tumor associated antigens severely limits the practicality of detecting neoplasms with antibody-directed paramagnetic contrast. So, while practical application of McAb-directed paramagnetic contrast in MRI will probably require the use of polymeric chelate conjugates as a means of dramatically increasing the ability of each $\mathrm{McAb}$ to reduce local proton relaxation times, the detection of neoplasms in particular will require maximal refinements in this approach as well as further advances in the development of tumor associated antigen-specific McAbs.

Finally, the most critical aspect of developing this technology will be the in vivo behavior of polymeric chelate conjugated McAbs. The influence of size, overall conformation, charge distribution, and other properties of different polymeric chelate formulations on the biodistribution, degree of extracirculatory penetrance, antigenicity and metabolic fate of its McAb conjugates will determine the limits of this approach, and thus, we believe, the practicality of using McAbs to specifically localize paramagnetic contrast agents for MRI.

\section{ACKNOWLEDGMENT}

We thank Dr. Robert Sharp of the Department of Chemistry, the University of Michigan, for allowing us to use his NMR spectrometer for the measurement of relaxation times.

\section{REFERENCES}

1. A. M. Keenan, J. C. Harbert, and S. M. Larson, J. Nucl. Med. 25, 531 (1985).

2. S. H. Koenig, C. Baglin, AND R. D. Brown III, Magn. Reson. Med. 1, 478 (1984).

3. R. B. LAUFFER AND T. J. BRADY, Magn. Reson. Imaging 3, 11 (1985).

4. R. L. Wahl, C. W. Parker, And G. W. Philpott, J. Nucl. Med. 24, 316 (1983).

5. B. A. Khaw, H. W. Strauss, S. L. Cehill, H. R. Soule, T. Edgington, and J. Cooney, J. Nucl. Med. 25, 592 (1984).

6. J. N. Weinstein, M. A. Steller, AND A. M. KeEnAN, Science 222, 423 (1983).

7. I. J. EAST, A. M. KEENAN, AND S. M. LARSON, Science 225, 938 (1984).

8. C. H. Park, M. A. Ebbert, R. R. Murphy, C. R. Lassman, R. C. Reba, W. C. Eckelman, K. Y. PAK, J. PoWe, Z. StePlewski, AND H. KoProwsKi, J. Nucl. Med. 25, 1158 (1983). 